\title{
Ileal true digestibility of amino acids in wheat milling by-products for pigs
}

\author{
Catherine JONDREVILLE ${ }^{\mathrm{a}}$, Jan VAN DEN BROECKE ${ }^{\mathrm{b}}$, \\ François Grosjean ${ }^{\mathrm{a}}$, Sabine VAN CAUWENBERGHE ${ }^{\mathrm{b}}$, François GATEL ${ }^{\mathrm{a} *}$ \\ a Institut Technique des Céréales et des Fourrages, \\ 8, avenue du Président Wilson, 75116 Paris, France \\ ${ }^{\mathrm{b}}$ Eurolysine, 153 rue de Courcelles, 75817 Paris Cedex 17, France
}

(Received 2 August 1999; accepted 30 November 1999)

\begin{abstract}
Ten batches of wheat milling by-products -3 of wheat middlings (WM), 4 of wheat feed (WF), 3 of wheat bran (WB) - were analysed and studied for their protein and amino acid ileal true digestibility (ITD). Each batch was tested on four castrated male pigs weighing between 35 and $95 \mathrm{~kg}$, and fitted with an end-to-end ileo-rectal anastomosis. In all types of by-products, lysine and threonine were among the least digestible amino acids, whereas methionine was among the most digestible ones. $\mathrm{N}$ and all amino acids ITD decreased significantly $(P<0.05)$ from WM to WF and to WB. In WM, the average N, lysine, threonine and methionine ITD values were 93.6, 90.8, 90.4 and $95.1 \%$, respectively. They decreased to $85.5,86.6,83.3$ and $91.5 \%$, respectively in WF and down to $70.1,68.3,68.4$ and $78.9 \%$, respectively in WB. N and all amino acids ITD was predicted according to either the ratio of the feedstuff fibre to amino acid concentrations, or the proportion of total $\mathrm{N}$ bound to the NDF (neutral detergent fibre) residue, or both. For most amino acids, the use of CF (crude fibre), $\mathrm{ADF}$ (acid detergent fibre) or ADL (acid detergent lignin) as fibre criteria provided accurate equations with coefficient of determination higher than $90 \%$.
\end{abstract}

wheat milling by-products / ileal digestibility / amino acids / pigs

Résumé - Digestibilité iléale des acides aminés des issues de meunerie chez le porc. L'objectif de ce travail était de mesurer la digestibilité iléale des acides aminés des issues de meunerie chez le porc et d'en déterminer les principaux facteurs de variation. Dans ce but, dix lots commerciaux de coproduits de meunerie ( 3 lots de farine basse, 4 lots de remoulage et 3 lots de sons) ont fait l'objet d'une caractérisation analytique et d'une mesure de digestibilité iléale des acides aminés. Les caractéristiques suivantes ont été analysées : azote, acides aminés, amidon, matière minérale, matière grasse, cellulose brute (CB), NDF (neutral detergent fibre), ADF (acid detergent fibre), ADL (acid detergent lignin) et teneur en azote du résidu NDF (NNDF). Chacun des lots a été testé sur quatre porcs mâles

* Correspondence and reprints

Tel.: (33) 254774810; fax: (33) 254722925; e-mail: fgatel@itcf.fr 
castrés, pesant entre 35 et 95 kg et préparés en anastomose iléo-rectale termino-terminale. Pour les trois types de co-produit, la digestibilité iléale vraie de la lysine et celle de la thréonine sont parmi les plus faibles alors que celle de la méthionine est parmi les plus élevées. La digestibilité iléale vraie de l'azote et de tous les acides aminés diminue significativement $(p<0,05)$ des farines basses aux remoulages puis aux sons. La digestibilité iléale vraie moyenne de l'azote, de la lysine, de la thréonine et de la méthionine est de, respectivement, 93,6, 90,8, 90,4 et 95,1\% pour les farines basses. Elle diminue jusqu'à, respectivement, $85,5,86,6,83,3$ et $91,5 \%$ pour les remoulages et jusqu'à, respectivement, $70,1,68,3,68,4$ et 78,9 \% pour les sons. La digestibilité iléale vraie de chacun des acides aminés peut être prédite à partir de la teneur en fibre de l'aliment et la quantité d'azote liée au résidu. Les meilleurs prédicteurs sont le rapport entre la teneur en CB, ADF ou ADL et la teneur en acide aminé, la proportion de l'azote total lié au résidu NDF, ou les deux. Pour la plupart des acides aminés, le coefficient de détermination des équations proposées excède $90 \%$.

co-produits de meunerie / digestibilité iléale / acides aminés / porc

\section{INTRODUCTION}

The by-products of wheat milling are of considerable economic significance as they represent $25 \%$ of the original grain. They are usually ranked in three different grades according to the proportions of the structures of the initial grain they contain: wheat middlings (WM) are made of starchy endosperm and particles of the aleurone layer, wheat feed (WF) contains endosperm and outer layers in variable proportion, whereas wheat bran (WB) contains outer layers with variable amounts of remaining starchy endosperm. If they can roughly be classified according to their fibre, ash and starch concentrations, they vary widely in composition according to the extent to which they are segregated and sold separately by a mill. Although they are traditionally used in pig feeding, only few authors reported values relative to their nitrogen and amino acid ileal digestibility [9, 27, 30].

The aim of this study, part of a more extensive work on amino acid digestibility in pig feeds [14], was to measure the nitrogen and amino acid ileal true digestibility in each of the three types of by-product and to evaluate the relevance of analytical criteria for its prediction.

\section{MATERIALS AND METHODS}

\subsection{Feedstuffs and experimental diets}

Ten commercial batches were selected to be representative of wheat milling byproducts used for feed in Europe: 3 batches of wheat middlings (WM1 to WM3), 4 of wheat feed (WF1 to WF4) and 3 of wheat bran (WB1 to WB3). All originated from Europe and six from France. Feedstuffs were ground in a hammer mill fitted with a 2-mm screen. The WM and WF based diets contained $945 \mathrm{~g}$ by-product and $55 \mathrm{~g}$ minerals and vitamins concentrate per $\mathrm{kg}$. Because of problems of feed intake, the WB batches were mixed with a corn starch/sugar mixture (1/1), in addition to the $55 \mathrm{~g}$ minerals and vitamins concentrate. The level of incorporation of WB1, WB2 and WB3 in the diet was 842,685 and $525 \mathrm{~g}$ per $\mathrm{kg}$, respectively.

\subsection{Animals and procedures}

Animals were castrated male pigs, pure bred Large White or (Large White $\times$ Landrace $) \times($ Large White $\times$ Piétrain $)$. They were surgically prepared with an end-to-end ileo-rectal anastomosis at a live weight of 25 to $30 \mathrm{~kg}[16,24]$. After a four-week recovery period following surgery, the animals entered a test period of 12 weeks. The 
experiments lasted from 1990 to 1993 and required the preparation of 20 growing pigs grouped into five batches of four animals. Each batch of feedstuff was tested on each of the four animals of only one group, at one period, both selected at random.

Animals were fed twice daily (8 a.m. and 4 p.m.) a diet in meal form mixed with water at the time of feeding (2 volumes water/ 1 volume meal). Drinking water was continuously available. The feeding scale was set at $90 \mathrm{~g}$ meal per kg metabolic weight (Live Weight ${ }^{0.75}$ ), i.e., taking into account the dry matter content of our wheat milling by-products based diets, around $72 \mathrm{~g}$ dry matter ingested per kg metabolic weight. Every week, the feed supply was individually adjusted, based on live weight values and their expected increases at four-week intervals.

Each test consisted in two phases, a fiveday adaptation period followed by a twoday collection period. This combination of the adaptation and collection periods was among those which allowed the most accurate measurement of nitrogen excreted by pigs fitted with an end-to-end ileo-rectal anastomosis [19]. During the latter period, the ileal digesta were totally collected twice a day, just after meal, and immediately stored at $4{ }^{\circ} \mathrm{C}$. At the end of the collection period, the ileal juices were homogenised on an animal basis, and two samples were taken: one was oven-dried $\left(80^{\circ} \mathrm{C}\right.$ for 72 hours), for dry matter determination, and the other one was freeze-dried prior to analysis.

\subsection{Chemical analysis}

All the chemical determinations (Tab. I), including amino acids, were performed in duplicate. Each batch of feedstuff, each diet and each sample of ileal chyme was analysed for nitrogen and amino acids. The nitrogen $(\mathrm{N})$ content was measured by the Kjeldahl method [12] with a Kjel-foss automatic apparatus (Foss-Electric, Denmark). The amino acid concentration was determined by chromatography in an ion exchange column (Beckman 6300, Beckman, USA) after a 23-hour hydrolysis in $\mathrm{HCl} 6 \mathrm{~N}$ at $110{ }^{\circ} \mathrm{C}$ [1]. The proline concentration was not measured. The S-containing amino acids were determined by the same method, after oxidation with performic acid. Tryptophan was separated by HPLC followed by fluorometric detection (Kontron Instrument, France). Hydrolysis was carried out in an alkaline bath (baryum hydroxide) at $125^{\circ} \mathrm{C}$ for 16 hours [15]. The dry matter (DM) content of each batch of feedstuff was determined by drying to constant weight at $103{ }^{\circ} \mathrm{C}$. For the determination of ash concentration, samples were placed at $550{ }^{\circ} \mathrm{C}$ for 8 hours. Neutral Detergent Fibre (NDF), Acid Detergent Fibre (ADF) and Acid Detergent Lignin (ADL) determinations were sequentially carried out [32], using Termamyl (Novo Nordisk, Denmark) for amylolytic treatment, and crude fibre (CF) according to the Weende method [11], by means of a Fibertec system (Tecator, Sweden). The concentration of $\mathrm{N}$ in the NDF residue (NNDF) was evaluated by treatment with the NDF solution and $\mathrm{N}$ determination on the residue, as described above. Fat concentration was measured, without hydrolysis prior to analysis [23], by means of a Soxtherm apparatus (Gerhardt, Germany). Starch concentration was derived by the Ewers method [22]: starch was hydrolysed by hot hydrochloric acid $(1.128 \mathrm{~g} / 100 \mathrm{ml})$ before measurement of specific rotation (POL.400, Isabiologie, France).

\subsection{Calculation and statistical analyses}

\subsubsection{Digestibility calculation}

At a first step, ileal apparent digestibility (IAD) was calculated from nitrogen and amino acid concentrations in the diets and in the ileal juices samples. IAD was corrected into ileal true digestibility (ITD), by subtracting the basal endogenous losses from the total amount of amino acid excreted. For 
Table I. Analytical characterisation of the feedstuffs.

\begin{tabular}{|c|c|c|c|c|c|c|c|c|c|c|}
\hline \multirow{3}{*}{$\begin{array}{l}\text { Batch } \\
\text { Origin }^{1}\end{array}$} & \multicolumn{3}{|c|}{ Wheat middlings } & \multicolumn{4}{|c|}{ Wheat Feed } & \multicolumn{3}{|c|}{ Wheat Bran } \\
\hline & WM1 & WM2 & WM3 & WF1 & WF2 & WF3 & WF4 & WB1 & WB2 & WB3 \\
\hline & NL & $\mathrm{F}$ & $\mathrm{F}$ & NL & $\mathrm{F}$ & $\mathrm{F}$ & $\mathrm{F}$ & $\mathrm{SF}$ & SF & $\mathrm{F}$ \\
\hline \multicolumn{11}{|l|}{$\mathrm{g} / \mathrm{kg} \mathrm{DM}$} \\
\hline $\mathrm{N}$ & 27.5 & 22.8 & 25.3 & 29.6 & 30.6 & 28.6 & 32.7 & 35.1 & 25.8 & 33.3 \\
\hline Fat & 34.4 & 29.3 & 26.7 & 46.4 & 32.4 & 44.8 & 47.3 & 40.5 & 44.5 & 56.1 \\
\hline $\mathrm{CF}$ & 11.5 & 14.4 & 19.8 & 50.9 & 46.0 & 60.2 & 61.4 & 111.6 & 98.0 & 67.2 \\
\hline Ash & 22.9 & 14.6 & 22.1 & 35.1 & 37.5 & 33.5 & 44.6 & 59.1 & 63.2 & 45.2 \\
\hline $\mathrm{NDF}$ & 67.7 & 67.3 & 117.7 & 208.1 & 211.4 & 254.4 & 279.9 & 404.8 & 482.4 & 315.5 \\
\hline $\mathrm{ADF}$ & 20.6 & 14.6 & 25.3 & 60.0 & 55.5 & 70.5 & 76.3 & 128.0 & 135.8 & 84.1 \\
\hline ADL & 4.6 & 3.7 & 6.3 & 15.8 & 14.2 & 19.4 & 22.4 & 44.9 & 37.5 & 29.1 \\
\hline NNDF & 0.9 & 1.1 & 1.4 & 1.7 & 1.8 & 2.1 & 2.6 & 5.8 & 5.6 & 6.4 \\
\hline Starch & 630.7 & 715.6 & 627.1 & 437.8 & 434.6 & 408.6 & 314.2 & 197.0 & 212.0 & 299.0 \\
\hline \multicolumn{11}{|l|}{$\mathrm{g} / 16 \mathrm{~g} \mathrm{~N}$} \\
\hline$\Sigma \mathrm{AA}^{2}$ & 85.6 & 77.0 & 85.9 & 82.3 & 82.3 & 75.2 & 80.3 & 81.2 & 79.0 & 72.8 \\
\hline Lys & 3.2 & 2.8 & 3.2 & 3.9 & 4.1 & 3.7 & 4.6 & 4.5 & 4.6 & 3.9 \\
\hline Thr & 2.9 & 2.9 & 2.8 & 3.3 & 3.3 & 3.1 & 3.3 & 3.4 & 3.5 & 3.1 \\
\hline Met & 1.7 & 1.7 & 1.7 & 1.9 & 1.7 & 1.6 & 1.7 & 1.8 & 1.7 & 1.5 \\
\hline Cys & 2.0 & 1.9 & 2.1 & 2.0 & 1.9 & 1.9 & 1.8 & 1.7 & 1.8 & 1.7 \\
\hline Trp & 1.1 & 1.0 & 1.2 & 1.2 & 1.2 & 1.2 & 1.2 & 1.5 & 1.5 & 1.3 \\
\hline Ala & 3.7 & 3.2 & 4.1 & 4.5 & 4.6 & 4.1 & 5.1 & 4.5 & 4.8 & 4.4 \\
\hline Arg & 5.3 & 4.0 & 5.2 & 5.9 & 6.6 & 5.9 & 6.7 & 7.3 & 7.2 & 6.1 \\
\hline Asp & 5.4 & 4.5 & 5.6 & 6.4 & 6.3 & 5.8 & 7.1 & 7.6 & 6.9 & 6.0 \\
\hline Glu & 27.7 & 25.3 & 27.7 & 21.5 & 21.3 & 18.3 & 17.6 & 17.0 & 15.9 & 16.0 \\
\hline Gly & 4.1 & 3.7 & 4.3 & 4.5 & 4.7 & 4.4 & 5.0 & 4.6 & 5.2 & 4.4 \\
\hline His & 2.4 & 2.8 & 2.2 & 2.4 & 2.3 & 2.6 & 2.2 & 2.6 & 2.9 & 2.6 \\
\hline Ile & 3.8 & 3.1 & 3.2 & 3.5 & 3.0 & 2.9 & 2.9 & 3.5 & 3.1 & 2.9 \\
\hline Leu & 6.6 & 5.9 & 6.5 & 6.1 & 6.0 & 5.6 & 5.8 & 6.0 & 5.7 & 5.4 \\
\hline Phe & 4.4 & 4.0 & 4.4 & 4.1 & 3.9 & 3.6 & 4.0 & 4.1 & 3.6 & 3.5 \\
\hline Ser & 4.7 & 4.4 & 4.4 & 4.6 & 4.2 & 4.3 & 4.0 & 4.3 & 4.4 & 4.1 \\
\hline Tyr & 2.1 & 1.9 & 2.5 & 2.0 & 2.5 & 2.1 & 2.7 & 2.4 & 2.1 & 1.9 \\
\hline Val & 4.5 & 3.8 & 4.7 & 4.6 & 4.6 & 4.1 & 4.7 & 4.4 & 4.3 & 4.0 \\
\hline
\end{tabular}

${ }^{1}$ NL: The Netherlands, F: France, SF: Finland.

2 Sum of all amino acids.

the correction, assumption was made that the basal endogenous losses were in constant proportion of the amount of dry matter ingested [18, 29]. The basal endogenous output was previously determined in our laboratory (Tab. II), in 20 replicates, on pigs prepared and managed according to the above described procedure and fed a protein-free diet containing maize starch (580 g per $\mathrm{kg}$ ), sugar (300 g per kg), wood cellulose
(35 g per $\mathrm{kg}$ ), soya oil (30 g per $\mathrm{kg}$ ) and a minerals and vitamins concentrate (55 g per $\mathrm{kg})$.

\subsubsection{Data analysis}

The effect of the batch (B) on amino acid ITD was analysed first within each type of wheat milling by-product. The effect of group of pigs could not be teste 
Table II. Effect of the batch within each type of by-product and effect of the type of by-product on $\mathrm{N}$ and amino acid ileal true digestibility $(\%)^{1}$.

\begin{tabular}{|c|c|c|c|c|c|c|c|c|c|c|c|c|c|c|}
\hline & \multicolumn{4}{|c|}{ Wheat middlings } & \multicolumn{4}{|c|}{ Wheat Feed } & \multicolumn{4}{|c|}{ Wheat Bran } & \multicolumn{2}{|c|}{ All types } \\
\hline & $\mathrm{m}^{2}$ & $\mathrm{se}^{2}$ & $\mathrm{~B}^{3}$ & $\mathrm{rsd}^{3}$ & $\mathrm{~m}$ & se & B & rsd & $\mathrm{m}$ & $\mathrm{se}$ & B & rsd & $\mathrm{T}^{4}$ & rsd \\
\hline $\mathrm{N}$ & $93.6 \mathrm{a}$ & 0.60 & NS & 1.4 & $85.5 b$ & 1.32 & $*$ & 2.5 & $70.1 \mathrm{c}$ & 3.03 & NS & 2.5 & $* * *$ & 3.5 \\
\hline$\Sigma \mathrm{AA}^{5}$ & $94.3 \mathrm{a}$ & 0.65 & $*$ & 1.0 & $88.8 b$ & 1.18 & $* *$ & 1.5 & $76.4 \mathrm{c}$ & 1.71 & NS & 1.5 & $* * *$ & 2.3 \\
\hline Lys & $90.8 \mathrm{a}$ & 1.04 & NS & 3.0 & $86.6 \mathrm{~b}$ & 1.12 & 0.07 & 2.5 & $68.3 \mathrm{c}$ & 1.95 & NS & 2.5 & $* * *$ & 4.1 \\
\hline Thr & $90.4 \mathrm{a}$ & 0.93 & NS & 2.1 & $83.3 b$ & 1.48 & $* *$ & 2.0 & $68.4 \mathrm{c}$ & 2.22 & NS & 2.0 & $* * *$ & 3.2 \\
\hline Met & $95.1 \mathrm{a}$ & 0.39 & NS & 1.6 & $91.5 b$ & 0.49 & NS & 1.5 & $78.9 \mathrm{c}$ & 2.97 & $*$ & 1.5 & $* * *$ & 2.4 \\
\hline Cys & $94.2 \mathrm{a}$ & 0.58 & 0.06 & 0.9 & $85.1 \mathrm{~b}$ & 1.27 & $* * *$ & 1.0 & $74.5 \mathrm{c}$ & 2.95 & $*$ & 1.0 & $* * *$ & 2.2 \\
\hline Trp & $91.2 \mathrm{a}$ & 0.90 & NS & 2.5 & $85.5 b$ & 0.54 & NS & 2.2 & $76.4 \mathrm{c}$ & 3.02 & $* *$ & 2.2 & $* *$ & 2.4 \\
\hline Ala & $86.5 \mathrm{a}$ & 2.81 & $* * *$ & 1.3 & $81.2 \mathrm{~b}$ & 3.28 & $* * *$ & 2.8 & $64.6 \mathrm{c}$ & 3.14 & NS & 2.8 & $* *$ & 4.1 \\
\hline Arg & $95.5 \mathrm{a}$ & 0.54 & NS & 1.1 & $93.9 \mathrm{~b}$ & 0.54 & $*$ & 1.0 & $86.9 \mathrm{c}$ & 1.68 & $*$ & 1.0 & $* *$ & 1.5 \\
\hline Asp & $90.1 \mathrm{a}$ & 1.15 & $* *$ & 1.0 & $84.8 b$ & 1.61 & $*$ & 2.5 & $70.0 \mathrm{c}$ & 1.49 & NS & 2.5 & $* * *$ & 3.3 \\
\hline Glu & $97.3 \mathrm{a}$ & 0.33 & 0.07 & 0.6 & $93.5 b$ & 0.82 & $* *$ & 1.1 & $84.7 \mathrm{c}$ & 1.04 & NS & 1.1 & $* * *$ & 1.7 \\
\hline Gly & $93.4 \mathrm{a}$ & 0.96 & 0.06 & 1.5 & $84.4 \mathrm{~b}$ & 1.26 & $*$ & 2.2 & $67.9 \mathrm{c}$ & 1.31 & NS & 2.2 & $* * *$ & 3.5 \\
\hline His & $95.8 \mathrm{a}$ & 0.38 & 0.08 & 0.6 & $90.2 b$ & 0.87 & $* *$ & 1.2 & $80.5 \mathrm{c}$ & 2.74 & $*$ & 1.2 & $* * *$ & 1.8 \\
\hline Ile & $93.4 \mathrm{a}$ & 0.76 & NS & 1.6 & $87.9 \mathrm{~b}$ & 1.06 & $* *$ & 1.6 & $74.7 \mathrm{c}$ & 2.86 & 0.06 & 1.6 & $* * *$ & 2.6 \\
\hline Leu & $94.3 \mathrm{a}$ & 0.66 & NS & 1.3 & $88.7 b$ & 1.15 & $* *$ & 1.5 & $74.6 \mathrm{c}$ & 2.49 & 0.07 & 1.5 & $* * *$ & 2.4 \\
\hline Phe & $95.1 \mathrm{a}$ & 0.71 & $*$ & 0.9 & $90.3 b$ & 1.35 & $* * *$ & 1.0 & $78.2 \mathrm{c}$ & 2.33 & 0.08 & 1.0 & $* * *$ & 2.3 \\
\hline Ser & $94.6 \mathrm{a}$ & 0.37 & NS & 1.2 & $87.9 \mathrm{~b}$ & 1.08 & $* *$ & 1.5 & $76.9 \mathrm{c}$ & 1.55 & NS & 1.5 & $* * *$ & 2.2 \\
\hline Tyr & $92.6 \mathrm{a}$ & 1.28 & $*$ & 1.2 & $89.1 \mathrm{~b}$ & 2.03 & $* * *$ & 1.5 & $77.2 \mathrm{c}$ & 4.00 & $*$ & 1.5 & $*$ & 3.4 \\
\hline Val & $91.5 \mathrm{a}$ & 1.17 & 0.07 & 2.0 & $86.1 \mathrm{~b}$ & 1.56 & $* *$ & 1.8 & $71.8 \mathrm{c}$ & 2.57 & 0.07 & 1.8 & $* * *$ & 2.8 \\
\hline
\end{tabular}

${ }^{1}$ Basal endogenous losses (g/kg DMI): N: 1.145; EAA: 3.969; Lys: 0.261; Thr: 0.253; Met: 0.086; Cys: 0.104; Trp: 0.081; Ala: 0.293; Arg: 0.201; Asp: 0.413; Glu: 0.511; Gly: 0.405; His: 0.088; Ile: 0.193; Leu: 0.297; Phe: 0.165 ; Ser: 0.247; Tyr: 0.110; Val: 0.261 .

$2 \mathrm{~m}$ : mean, se: standard error, rsd: residual standard deviation.

${ }^{3}$ Effect of the batch within in each type of by-product ( $P$-values).

${ }^{4}$ Effect of the type of by-product tested against the batch nested within the type ( $P$-values). Values with different character in the same row differ significantly at $P<0.05$.

NS: $P>0.10 ; *: P<0.05 ; * *: P<0.01 ; * * *: P<0.001$.

${ }^{5}$ Sum of all amino acids.

independently of the batch of wheat milling by-product. However, we checked the absence of $\mathrm{LW}$ and $\mathrm{LW} \times \mathrm{B}$ interaction effects by a covariance analysis. An overall analysis of variance was performed in order to evaluate the effect of the type of wheat milling by-product relative to the residual variation between batches. The overall model included the following items: the type of by-product (T) and the batch nested within the type $\mathrm{B}(\mathrm{T})$. The effect of the type (T) was tested against the batch nested within the type $(\mathrm{B}(\mathrm{T}))$. A Tukey's Studen- tized Range test was used for comparison of means. Analyses of variance and covariance were performed using the GLM procedure of the SAS statistical software [26].

Attempts for prediction of $\mathrm{N}$ and amino acids ITD were made through regressions of the ileal true digestibility values on the analytical characteristics of the diets $(\mathrm{g} / \mathrm{kg} \mathrm{DM})$ and the ratios of the analytical characteristics to the amino acid concentrations [30]. These ratios have the advantage of being independent of the level of 
incorporation of the feedstuff in the experimental diet, contrary to the simple dietary components concentrations. Regression analyses were performed by means of the STEPWISE procedure of the MINITAB statistical software [20].

\section{RESULTS}

For five batches of feedstuff, digestibility was calculated on three replicates only because of the death of pigs during experiments or problems of low feed intake. The average live weights of pigs fed WM and WF were in the same range (65 to $92 \mathrm{~kg}$ ), whereas they were lower for pigs fed WB (37 to $67 \mathrm{~kg}$ ).

\subsection{Analytical characteristics and amino acids concentration}

The analytical composition of each batch of wheat milling by-product is given in Table I. The fibre (CF, NDF, ADF, ADL) as well as the ash concentrations increased, whereas the starch concentration decreased from WM to WF and to WB. The nitrogen concentration was in the same range in WF and WB, and higher than in WM. The proportion of nitrogen bound to the NDF residue was by far higher in WB (16.6 to $21.8 \%$ ) than in WF and WM (3.2 to 5.4\% and 5.6 to $7.8 \%$, respectively). Whatever the type of by-product, methionine, cystine, tryptophan and tyrosine were among scarce amino acids. Glutamic acid displayed the highest concentration, followed by arginine, aspartic acid, leucine and serine. However the amino acid pattern varied: the lysine, alanine, arginine, aspartic acid and glycine concentrations increased from WM to WB, whereas the glutamic acid and phenylalanine concentrations decreased.

\section{2. $\mathrm{N}$ and amino acid ITD}

Within a single type, the LWxB interaction on amino acid ITD was never signifi- cant $(P>0.05)$, except for $\mathrm{N}$ and glycine in WF. In addition, the LW effect was never significant (results not shown). $\mathrm{N}$ and amino acid ITD values, the results of the analysis of variance performed for each type of byproduct and the results of the overall analysis of variance are presented in Table II. Whatever the type of by-product, methionine, arginine, glutamic acid, histidine and phenylalanine were among the most digestible amino acids whereas lysine, threonine, alanine and aspartic acid were among the least digestible ones. Glycine also was among the least digestible amino acids in WB and WF.

Significant differences $(P<0.05)$ between batches appeared in the three types of byproducts. The effect of the type of by-product, tested against the effect of the batch nested within the type, was significant for all amino acids and even highly significant $(P<0.001)$ for most of them: amino acid ITD decreased from WM to WF and to WB. Overall, the sum of all amino acids ITD decreased by 5.5 percentage units from WM to WF and by 12.4 additional percentage units to WB. These differences were variable according to the amino acid: the greatest differences were observed for glycine, lysine, threonine, alanine and aspartic acid and the smallest for arginine, glutamic acid, tryptophan and histidine.

\subsection{Prediction of $\mathbf{N}$ and amino acid ITD}

The predicting equations obtained for essential and semi-essential amino acids are shown in Table III. ITD of each amino acid was predicted according to either the ratio of fibre to its concentrations, or the ratio of the $\mathrm{N}$ in NDF residue to $\mathrm{N}$ concentrations, or both together. For most amino acids, ADF, CF or ADL provided equations with quite similar residual standard deviation and coefficient of determination. The use of NDF as fibre criteria led to less accurate equations. 
Table III. Prediction of $\mathrm{N}$ and essential and semi-essential amino acids ileal true digestibility (\%) in wheat milling by-products according to the ratio of ADF, CF or ADL to the amino acid and NNDF to the $\mathrm{N}$ concentrations in the feedstuffs.

\begin{tabular}{|c|c|c|c|c|c|c|c|c|c|c|}
\hline & Intercept & $\mathrm{sd}^{1}$ & & & & $\mathrm{NNDF} / \mathrm{N}^{3}$ & $\mathrm{sd}$ & $\mathrm{P}^{2}$ & $\mathrm{rsd}^{4}$ & $r^{24}$ \\
\hline Arg & 98.0 & 0.6 & & & & -58.5 & 4.9 & $* * *$ & 1.0 & 94.6 \\
\hline Phe & 98.7 & 1.1 & & & & -109 & 9 & $* * *$ & 1.8 & 94.8 \\
\hline Tyr & 96.9 & 2.0 & & & & -106 & 17 & $* * *$ & 3.5 & 82.6 \\
\hline \multirow[t]{2}{*}{ Val } & 96.0 & 1.2 & & & & -128 & 10 & $* * *$ & 2.0 & 95.5 \\
\hline & Intercept & $\mathrm{sd}^{1}$ & $\mathrm{ADF} / \mathrm{AA}^{3}$ & $\mathrm{sd}$ & $\mathrm{P}$ & $\mathrm{NNDF} / \mathrm{N}$ & $\mathrm{sd}$ & $\mathrm{P}$ & $\mathrm{rsd}^{4}$ & $r^{24}$ \\
\hline $\mathrm{N}$ & 97.9 & 2.9 & -6.50 & 1.12 & $* * *$ & & & & 4.7 & 80.7 \\
\hline$\Sigma \mathrm{AA}^{5}$ & 98.6 & 0.8 & -10.2 & 3.0 & $*$ & -73.8 & 12.9 & $* * *$ & 1.2 & 98.0 \\
\hline Lys & NS & & & & & & & & & \\
\hline Thr & 96.3 & 1.2 & -0.706 & 0.190 & $* *$ & -78.0 & 17.8 & $* *$ & 1.7 & 97.4 \\
\hline Met & 100 & 1 & -0.251 & 0.779 & $*$ & -62.1 & 15.7 & $* *$ & 1.5 & 96.9 \\
\hline Cys & 96.4 & 2.3 & -0.594 & 0.098 & $* * *$ & & & & 3.8 & 82.0 \\
\hline Trp & 96.6 & 0.8 & -0.312 & 0.047 & $* * *$ & -35.2 & 9.9 & $* *$ & 1.2 & 97.6 \\
\hline His & 101 & 1 & -0.547 & 0.107 & $* * *$ & -40.5 & 12.4 & $*$ & 1.4 & 96.5 \\
\hline Ile & 98.4 & 0.5 & -0.475 & 0.074 & $* * *$ & -75.5 & 8.0 & $* * *$ & 0.8 & 99.2 \\
\hline \multirow[t]{2}{*}{ Leu } & 98.4 & 0.6 & -0.781 & 0.160 & $* * *$ & -86.0 & 9.5 & $* * *$ & 0.9 & 99.1 \\
\hline & Intercept & $\mathrm{sd}^{1}$ & $\mathrm{CF} / \mathrm{AA}^{3}$ & $\mathrm{sd}$ & $\mathrm{P}$ & $\mathrm{NNDF} / \mathrm{N}$ & $\mathrm{sd}$ & $\mathrm{P}$ & $\mathrm{rsd}^{4}$ & $r^{24}$ \\
\hline $\mathrm{N}$ & 99.1 & 2.5 & -8.79 & 1.23 & $* * *$ & & & & 4.0 & 86.5 \\
\hline$\Sigma \mathrm{AA}$ & 98.9 & 0.6 & -14.0 & 3.0 & $* * *$ & -72.6 & 9.8 & $* * *$ & 1.0 & 98.7 \\
\hline Lys & 98.6 & 1.2 & -0.644 & 0.280 & $*$ & -119 & 14 & $* * *$ & 1.6 & 98.0 \\
\hline Thr & 96.8 & 0.9 & -0.930 & 0.182 & $* * *$ & -78.3 & 13.2 & $* * *$ & 1.4 & 98.4 \\
\hline Met & 100 & 1 & -0.267 & 0.121 & 0.06 & -70.9 & 18.2 & $* *$ & 1.8 & 95.5 \\
\hline Cys & 97.5 & 1.7 & -0.809 & 0.092 & $* * *$ & & & & 2.8 & 90.6 \\
\hline Trp & 96.7 & 1.2 & -0.356 & 0.076 & $* * *$ & -43.4 & 12.4 & $*$ & 1.6 & 95.8 \\
\hline His & 101 & 1 & -0.663 & 0.124 & $* * *$ & -45.0 & 11.2 & $* *$ & 1.4 & 96.8 \\
\hline Ile & 98.7 & 0.6 & -0.585 & 0.116 & $* * *$ & -79.0 & 9.5 & $* * *$ & 1.0 & 98.9 \\
\hline \multirow[t]{2}{*}{ Leu } & 99.6 & 0.6 & -0.981 & 0.201 & $* * *$ & -88.3 & 9.0 & $* * *$ & 0.9 & 99.1 \\
\hline & Intercept & $\mathrm{sd}^{1}$ & $\mathrm{ADL} \mathrm{AA}^{3}$ & $\mathrm{sd}$ & $\mathrm{P}$ & $\mathrm{NNDF} / \mathrm{N}$ & $\mathrm{sd}$ & $\mathrm{P}$ & $\mathrm{rsd}^{4}$ & $r^{24}$ \\
\hline $\mathrm{N}$ & 97.8 & 1.6 & -22.2 & 2.0 & $* * *$ & & & & 2.7 & 93.8 \\
\hline$\Sigma \mathrm{AA}$ & 98.2 & 0.6 & -43.8 & 10.2 & $* *$ & -57.7 & 13.7 & $* *$ & 1.1 & 98.6 \\
\hline Lys & 98.1 & 1.1 & -2.18 & 0.88 & $*$ & -104 & 19 & $* * *$ & 1.6 & 98.1 \\
\hline Thr & 95.7 & 0.8 & -2.91 & 0.84 & $* * *$ & -55.2 & 17.1 & $*$ & 1.4 & 98.4 \\
\hline Met & NS & & & & & -106 & 11 & $* * *$ & 2.2 & 92.4 \\
\hline Cys & 96.1 & 1.4 & -1.97 & 0.20 & $* * *$ & & & & 2.5 & 92.3 \\
\hline Trp & 95.9 & 1.1 & -1.42 & 0.13 & $* * *$ & & & & 1.7 & 94.1 \\
\hline His & 99.8 & 1.1 & -2.63 & 0.23 & $* * *$ & & & & 1.7 & 94.2 \\
\hline Ile & 97.9 & 0.7 & -1.78 & 0.44 & $* *$ & -65.1 & 14.7 & $* *$ & 1.2 & 98.4 \\
\hline Leu & 98.9 & 0.6 & -2.93 & 0.76 & $* *$ & -76.4 & 14.0 & $* * *$ & 1.1 & 98.8 \\
\hline
\end{tabular}

1 sd: standard deviation.

$2 P$-values: *: $P<0.05 ; * *: P<0.01 ; * * *: P<0.001$.

${ }^{3}$ ADF/AA resp. CF/AA, ADL/AA: ratio of feedstuff ADF resp. CF and ADL to amino amino acid concentrations $(\mathrm{g} / \mathrm{g})$; NNDF/N: ratio of feedstuff $\mathrm{N}$ in the NDF residue to total $\mathrm{N}$ concentrations $(\mathrm{g} / \mathrm{g})$.

${ }^{4}$ rsd: residual standard deviation; $\mathrm{r}^{2}$ : coefficient of determination.

${ }^{5} \Sigma \mathrm{AA}:$ sum of all amino acids. 


\section{DISCUSSION}

\subsection{Chemical composition of the by-products batches}

The variability in analytical characteristics and protein amino acid profiles within each type of by-products fits in with the variability reported in literature $[2,25]$. It originates from the variable amounts of pericarp, aleurone and endosperm fractions recovered in each of the by-products batches. However, except for WF4, which exhibits analytical characteristics very close to those of WB3, and an amino acid pattern very close to that of wheat brans, the types of by-products are clearly differentiated.

The increasing concentrations of the dietary protein in lysine, alanine, arginine, aspartic acid and glycine from WM to WB is in accordance with the high concentration of these amino acids in wheat pericarp and aleurone, as well as in wheat functional proteins (albumins and globulins). On the contrary, the decreasing concentration of glutamic acid and phenylalanine from WM to WB is consistent with their high concentration in wheat endosperm as well as in wheat storage proteins (prolamins and glutelins) [4, 25].

\section{2. $\mathrm{N}$ and amino acid ITD}

Some differences in physiological status, age or weight have appeared between groups of animals and some batches of feedstuff have been tested later than others within the same group. Therefore the reliability of our data was based on the initial assumption of the absence of effects, not only of pig ageing or live weight, but also of other characteristics of the groups on amino acid digestibility.

These animals were growing pigs housed in the same environment, fed at constant levels of dry matter intake and used within a relatively narrow range of body weight. In such conditions, there is no indication in the literature of significant variations affecting ileal digestibility of the amino acids other than those associated with changes in dietary components. In accordance with previous results $[3,17]$, the analysis of the effect of live weight confirmed that this parameter was of little influence on amino acid ileal digestibility in pigs fitted with an end-to end ileo-rectal anastomosis.

The overall decrease in amino acid ITD from WM to WB was previously reported [30]. A similar ranking of amino acids for ITD was previously observed in wheat milling by-products [9, 26, 29], as well as in wheat (e.g. [5, 7, 8, 10, 27, 31]). However, the overall high digestibility of methionine is in agreement with some literature data [27], but at variance with other ones [9, 30].

IAD values are biased by the AA concentration in the experimental diet [6], which hampers a reliable comparison of data together. Correcting total ileal AA flow by the basal endogenous losses aims at overcoming this methodological problem and at getting additive supply of digestible AA [8, 29]. Although the average basal endogenous losses we calculated from 20 individual measurements are almost twice lower than the value proposed by Wünsche et al. in a literature review, they remain in the range of variation proposed by this author ( 2.22 $\pm 0.88 \mathrm{~g} / \mathrm{kg}$ DM) [33]. For ITD calculation, ileal excretion of amino acid being corrected for basal endogenous losses only, factors affecting either the feed specific endogenous losses, or the undigested dietary fraction, or both, may influence the ranking of types of by-products or of batches within a type with regards to amino acid ITD, as well as differences between amino acids [29].

Relatively high concentrations of threonine, alanine, aspartic acid and glycine in endogenous protein, compared to dietary protein, undoubtedly contribute to their overall low ITD in wheat milling by-products [30]. In addition, as previously demonstrated with protein-free diets, ileal $\mathrm{N}$ endogenous losses increase when pigs are fed increasing 
amounts of fibre (NDF) [19, 28]. The mechanisms involved are a direct stimulation of digestive secretion, a sloughing of epithelial cells but also the adsorption of peptides and amino acids on the fibre or the alteration of the rate of passage through the intestinal tract [21]. This phenomenon probably contributes to the general decrease in digestibility from WM to WB. It may also explain the great decrease in ITD of those amino acids which are highly concentrated in the endogenous protein compared to the dietary protein. Dietary fibre may also impair ileal true digestibility by encapsulating dietary protein and limiting its release in the intestinal lumen $[10,13,30]$. As the proportion of total $\mathrm{N}$ bound to the NDF residue increases greatly from $\mathrm{WM}$ to $\mathrm{WB}$, it probably partly explains the decrease in digestibility from WM to WB. This phenomenon is also probably involved in the overall low digestibility of alanine, aspartic acid and lysine, highly concentrated in the fibrous part of the wheat grain, as well as in the great decrease in ITD for these amino acids from WM to WB [4, 25].

On the contrary, the most digestible amino acids are either mainly located in the endosperm fraction of the grain (glutamic acid, histidine and phenylalanine) and, therefore, more accessible to the digestive enzymes, or scarce in the endogenous protein compared to the dietary protein (methionine, histidine, glutamic acid and phenylalanine). The overall high arginine ITD, despite its high concentration in the most fibrous part of the grain may originate from a quick release from protein and a rapid absorption [10].

\subsection{Prediction of $\mathrm{N}$ and amino acid ITD}

As previously reported by Sève et al. [30], both the dietary fibre concentration relative to the amino acid concentration and the proportion of nitrogen bound to the NDF residue were relevant predictors for amino acid ileal true digestibility in wheat milling by-products. The predicting equations proposed are accurate and meaningful as they may represent the probable increase of both endogenous losses and the amount of undigested protein from WM to WB.

At the end, reliable prediction of $\mathrm{N}$ and amino acid ITD in wheat milling by-products can be performed from their fibre and NNDF concentrations. However, our study failed to quantify the relative weight of losses from endogenous and dietary origins in the total losses. Further investigations, involving the partition of amino acid in digesta according to their origin, would enhance our understanding of the mechanisms involved during digestion.

\section{ACKNOWLEDGEMENTS}

Part of the results were obtained with the financial support of the Ministère de l'Education Nationale, de l'Enseignement Supérieur et de la Recherche (ACTA programme) and the European Commission (CAMAR CT 91-0112). The work was performed in collaboration with MENGVOEDER UT-DELFIA (NL), SUOMEN REHU (SF) and SANOFI SANTE NUTRITION ANIMALE (F). The authors wish to thank the staffs of the ITCF pig unit research, the ITCF laboratory, the ITCF methods department and the EUROLYSINE laboratory for their technical assistance. They gratefully acknowledge B. Sève (Institut National de la Recherche Agronomique, F), R. Pinot (SANOFI SANTE NUTRITION ANIMALE, F), D. Sauvant (Institut National Agronomique de Paris-Grignon, F) and G. Rychen (École Nationale Supérieure d'Agronomie et des Industries Alimentaires, Nancy, F) for their advises in preparing this paper.

\section{REFERENCES}

[1] AFNOR, Aliments des animaux, dosage des acides aminés, NF V 18-113, Association Française de Normalisation, Paris-La Défense, 1993.

[2] Bach Knudsen K.E., Carbohydrates and lignin content of plant materials used in animal feeding, Anim. Feed Sci. Technol. 67 (1997) 319-338. 
[3] Bodin J.C., McMillan E., Maillard R., van Kempen T., Williams P.E.V., Effect of time postsurgery on the measurement of ileal digestibility in ileal rectal anastomosed pigs, in: Proc. Ann. Meet. Br. Soc. Anim. Sci., Br. Soc. Anim. Sci. Publ., March, Scarborough, UK, 1998, p. 162.

[4] Chung O.K., Pomeranz Y., Amino acids in cereal proteins and protein fractions, in: Finley J.W., Hopkins D.T (Eds.), Digestibility and amino acids availability in cereals and oilseeds, American Association of Cereal Chemists, St-Paul, Minnesota, USA, 1985, pp. 65-103.

[5] De Lange C.F.M., Souffrant W.B., Sauer W.C., Real ileal protein and amino acid digestibilities in feedstuffs for growing pigs as determined with the ${ }^{15} \mathrm{~N}$-isotope dilution technique, J. Anim. Sci. 68 (1990) 409-418.

[6] Fan M.Z., Sauer W.C., Hardin R.T., Lien K.A., Determination of apparent ileal digestibility in pigs: effect of dietary amino acid level, J. Anim. Sci. 72 (1994) 2851-2859.

[7] Fuller M.F., Cadenhead A., Brown D.S., Brewer A.C., Carver M., Robinson R., Varietal differences in the nutritive value of cereal grains for pigs, J. Agric. Sci. (Cambridge) 113 (1989) 149-163.

[8] Furuya S., Kaji Y., Additivity of the apparent and true ileal digestible amino acid supply in barley, maize, wheat or soya-bean meal based diets for growing pigs, Anim. Feed Sci. Technol. 32 (1991) 321-331.

[9] Furuya S., Kaji Y., Asano T., Murayama R., Ileal digestibilities of amino acids in wheat bran, rice bran, rapeseed meal, grain sorghum, meat and bone meal and feather meal for growing pigs, Jpn J. Zootech. Sci. 59 (1988) 407-413.

[10] Green S., Bertrand S.L., Duron M.J.C., Maillard R.A., Digestibility of amino acids in maize, wheat and barley meal, measured in pigs with ileo-rectal anastomosis and isolation of the large intestine, J. Sci. Food Agric. 41 (1987) 29-43.

[11] ISO, Agricultural food products - determination of crude fibre - general method, ISO 5498, International Standards of Organisation, Genève, 1981.

[12] ISO, Animal feeding stuffs - determination of nitrogen for the calculation of crude protein content - Kjeldahl methods, ISO 5983, International Standards of Organisation, Genève, 1997.

[13] Johansen H.N., Bach Knudsen K.E., Wood P.J., Fulcher R.G., Physico-chemical properties and the degradation of oat bran polysaccharides in the gut of pigs, J. Sci. Food Agric. 73 (1997) 81-92.

[14] Jondreville C., van den Broecke J., Gatel F., Van Cauwenberghe S., Ileal digestibility of amino acids in feedstuffs for pigs, EurolysineITCF, Paris, France, 1995, 53 p.
[15] Landry J., Delhaye S., Simplified procedure for determination of tryptophan of foods and feedstuffs from barytic hydrolysis, J. Agric. Food Chem. 40 (1992) 776-779.

[16] Laplace J.P., Darcy-Vrillon B., Perez J.P., Henry Y., Giger S., Sauvant D., Associative effects between two fibre sources on ileal and overall digestibilities of amino acids, energy and cellwall components in growing pigs, Br. J. Nutr. 61 (1989) 75-87.

[17] Laplace J.P., Souffrant W.B., Hennig U., Chabeauti E., Février C., Measurement of precaecal dietary protein and plant cell wall digestion in pigs: comparison of four surgical procedures for ileorectal anastomosis, Livest. Prod. Sci. 40 (1994) 313-328.

[18] Low A.G., Digestibility and availability of amino acids from feedstuffs for pigs: a review, Livest. Prod. Sci. 9 (1982) 511-520.

[19] Mariscal-Landin G., Sève B., Colleaux Y., Lebreton Y., Endogenous amino nitrogen collected from pigs with end-to-end ileorectal anastomosis is affected by the method of estimation and altered by dietary fiber, J. Nutr. 125 (1995) 136-146.

[20] MINITAB, MINITAB reference manual (release 11), MINITAB Inc., USA, 1996.

[21] Nyachoti C.M., De Lange C.F.M., McBride B.W., Schulze H., Significance of endogenous gut nitrogen losses in the nutrition of growing pigs: a review, Can. J. Anim. Sci. 77 (1997) 149-163.

[22] OJEC, Dosage de l'amidon - méthode polarimétrique, EEC 3e-72/199, Official Journal of the European Communities, 27 November 1980.

[23] OJEC, Dosages des matières grasses brutes, EEC 2e-71/393, Official Journal of the European Communities, 18 January 1984.

[24] Picard M., Bertrand S., Genin F., Maillard M., Digestibilité des acides aminés : intérêt de la technique du shunt iléo-rectal chez le porc, Journées Rech. Porcine en France 16 (1984) 355-360.

[25] Pomeranz Y., Chemical composition of kernel structures, in: Pomeranz Y. (Ed.), Wheat, Chemistry and Technology, 3rd edn., Vol. 1, American Association of Cereal Chemists, St-Paul, Minnesota, USA, 1988, pp. 97-158.

[26] SAS, SAS/STAT ${ }^{\circledR}$, User's Guide (4th edn., Vol. 2), SAS Inst. Inc., Cary, NC, 1990.

[27] Sauer W.C., Stothers S.C., Parker R.J., Apparent and true availabilities of amino acids in wheat and milling by-products for growing pigs, Can. J. Anim. Sci. 57 (1977) 775-784.

[28] Schulze H., van Leeuven P., Verstegen M.W.A., van den Berg J.W.O., Dietary level and source of neutral detergent fiber and ileal endogenous nitrogen flow in pigs, J. Anim. Sci. 73 (1995) 441-448. 
[29] Sève B., Henry Y., Protein utilization in non ruminants, in: Nunes A.F., Portugal A.V., Costa J.P., Ribeiro J.R. (Eds.), Proc. 7th Symp. on Protein Metabolism and Nutrition, Vale de Santarém, Portugal, 24-27 May 1995, EAAP Pub. $\mathrm{n}^{\circ}$ 81, 1996, pp. 59-82.

[30] Sève B., Mariscal-Landin G., Février C., Lechevestrier Y., Prédiction de la digestibilité iléale des acides aminés chez le porc : le cas des issues de blé, Journées Rech. Porcine en France 26 (1994) 259-266.

[31] Taverner M.R., Hume I.D., Farell D.J., Availability to pigs of amino acids in cereal grains. 2 .
Apparent and true ileal availability, Br. J. Nutr. 46 (1981) 159-171.

[32] van Soest P.J., Robertson J.B., Lewis A., Methods for dietary fiber, neutral detergent fiber and non starch polysaccharides in relation to animal nutrition, J. Dairy Sci. 74 (1991) 3583-3597.

[33] Wünsche J., Herrmann U., Meinl M., Hennig U., Kreienbring F., Zwierz P., Einfluss exogener Faktoren auf die präzäkale Nährstoff - und Aminosaürenresorption, ermittelt an Schweinen mit ileo-rektal Anastomosen. 1. Mitteilung: Einfluss des Zerkleinerungsgrades von Getreide, Arch. Tierernähr. (Berlin) 37 (1987) 745-764. 